\title{
Narratives great and small: neighbourhood change, place and identity in Notting Hill
}

\author{
Graham P. Martin
}

\begin{abstract}
The area of Notting Hill in west London has been subject to much media coverage in recent years, which, along with substantial gentrification, has given rise to an image of the area as the epitome of fashionable London. This study investigates the views of those marginal to gentrification and mediated representation on their feelings about the local area, its image and their changing neighbourhoods. Many participants in the research resented some of the more recent changes in Notting Hill and the area's representation in the media. However, in contrast to expectations, most of the more working-class respondents involved in the research did not articulate much emotional attachment to the area. They were more concerned with what might be termed the material aspects of life in Notting Hill: convenience, facilities, safety and so on. In contrast, the more middle-class respondents frequently spoke of their regret of the changes to the area, such as the loss of independent shops, and the reduction in diversity. Paradoxically, the loss of working-class landscapes seems a relatively middle-class worry. The symbolically important landscapes described by working-class respondents were related to more immediate, material issues, in which gentrification was only a relatively minor concern.
\end{abstract}

Published in:

International Journal of Urban and Regional Research 29(1): 67-88
http://www.blackwellpublishing.com/journal.asp?ref=0309-1317
htt:://www.blackwell-synergy.com/links/doi/10.1111/j.1468-2427.2005.00570.x/abs/
doi:10.1111/j.1468-2427.2005.00570.x

\section{Introduction}

The last 15 years or so have witnessed much academic interest in the cultural aspects of contemporary shifts in the structure of urban space. Alongside accounts of the economic processes underlying such trends as gentrification and globalization which are seen as fundamental to the social and spatial restructuring of the post-Fordist city, an increasing amount of attention has been paid to the importance of the cultural in such processes. Writers such as Zukin (1992) and Smith (1996) have focused on how the changing tastes and 'lifestyle choices' of the 'new middle class' have interacted with such economic changes as relative declines in land value to provide opportunities for developers and individuals to profit from neighbourhood 'rehabilitation' in the inner city. In this context, gentrification is seen as a concurrent symbolic and material recasting of a neighbourhood in accordance with the dominant tastes of the incoming groups: "gentrification-a process that seems to reassert a purely local identityrepresents downtown's social and cultural transformation in terms of an international market culture" (Zukin, 1991: 187). The local incumbent population is disenfranchised from this recasting, and so the re-imaging of such areas represents a violent imposition of a dominant perspective of place.

Studies such as these provide insightful commentaries on the power of developers and other dominant groups to rewrite the symbolism of places as they effect material change. But what they often lack is direct accounts of the attitudes towards these processes of the actors involved (Burgess, 1990) - particularly the subordinate populations whose neighbourhoods are being symbolically and materially overhauled. As Rose (1994: 48) observed 10 years ago in 


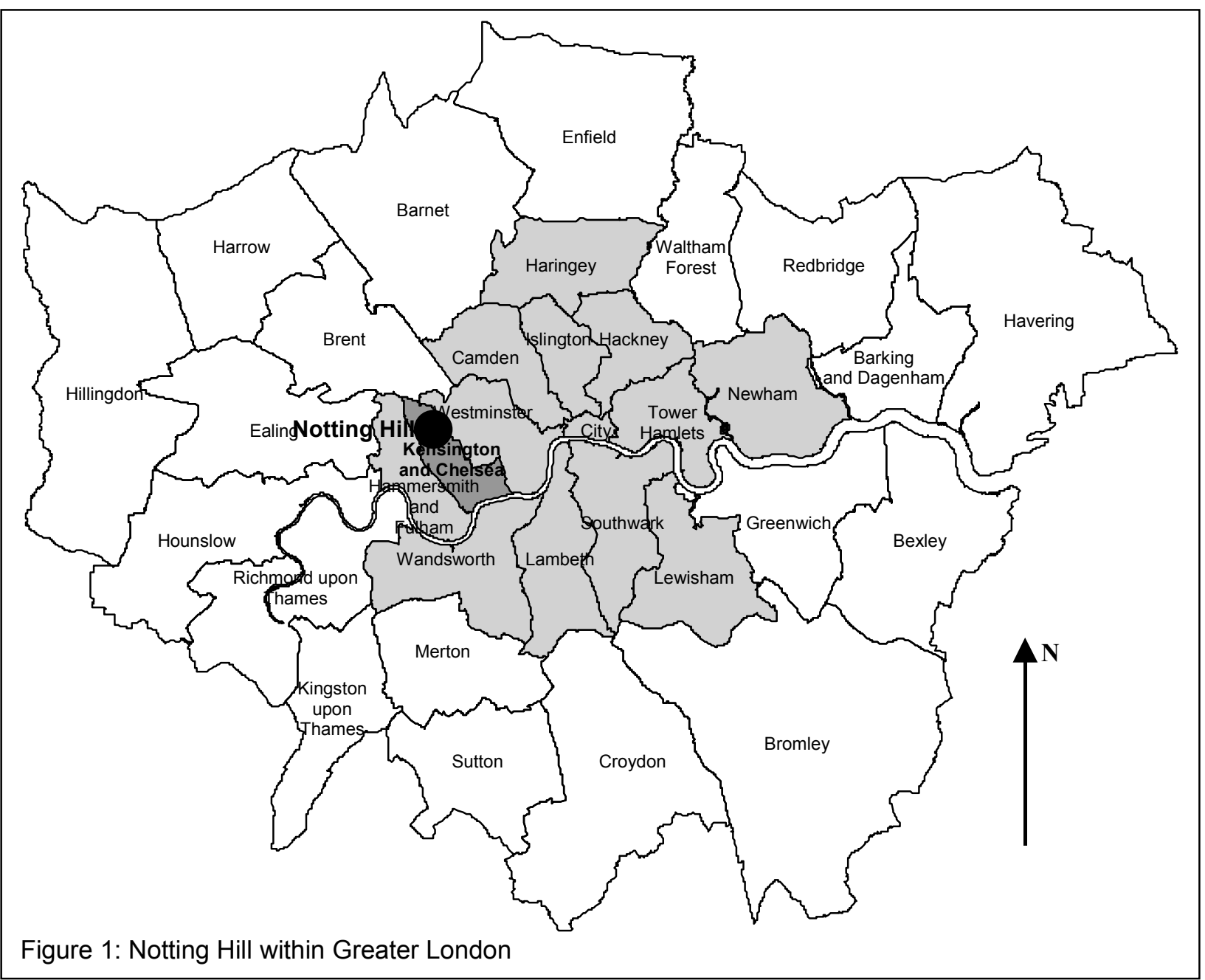

relation to cultural geography, attempting to uncover the ideology of dominant cultural forms "has the insidious effect of translating most geographers' interest in power into an interest in the powerful." Her comments remain valid today, at least in relation to studies of gentrification, where explorations of the connections between place and identity in the postmodern urban landscape have frequently relied upon the interpretations of the authors themselves. Compounded by the difficulties of coherently researching socially diverse neighbourhoods (Abu-Lughod, 1994), most studies of gentrification have tended to concentrate on the views of the gentrifiers rather than the poorer groups who are marginalized within their neighbourhoods or even pushed out altogether (Slater et al., 2004). When it comes to applied empirical research involving the 'real people'-in particular the 'non-gentrifiers' - who inhabit those places, few have taken seriously Keith and Pile's (1993: 8) assertion that "landscape is made in the image of capital but this is not its sole image. When we walk the streets ... we are at once invoking a host of competing spatialities, not a straightforward spatialized reference with a correspondent true meaning."1

This paper describes an attempt to address this agenda in an area more subject than most to the kinds of processes described above, the part of west London known as Notting Hill or North Kensington (Figures 1 and 2). Originally part of the outward exodus of the capital's rich and not-so-rich in the mid-nineteenth century, the area has seen wide fluctuations in fortunes since then, from extreme poverty and racial tension in the 1950s to its status now as a rapidly gentrifying and extremely fashionable section of the city. Though the upward rise of the area was first tracked in the early 1960s by Ruth Glass (1964), it is only since the 1990s that Notting Hill

${ }^{1}$ Though see Burgess and Wood (1988), Mills (1993), Western (1993), May (1996), Albrow (1997), Eade (1997a) and Blokland (2001) for notable exceptions in the field of gentrification studies. 


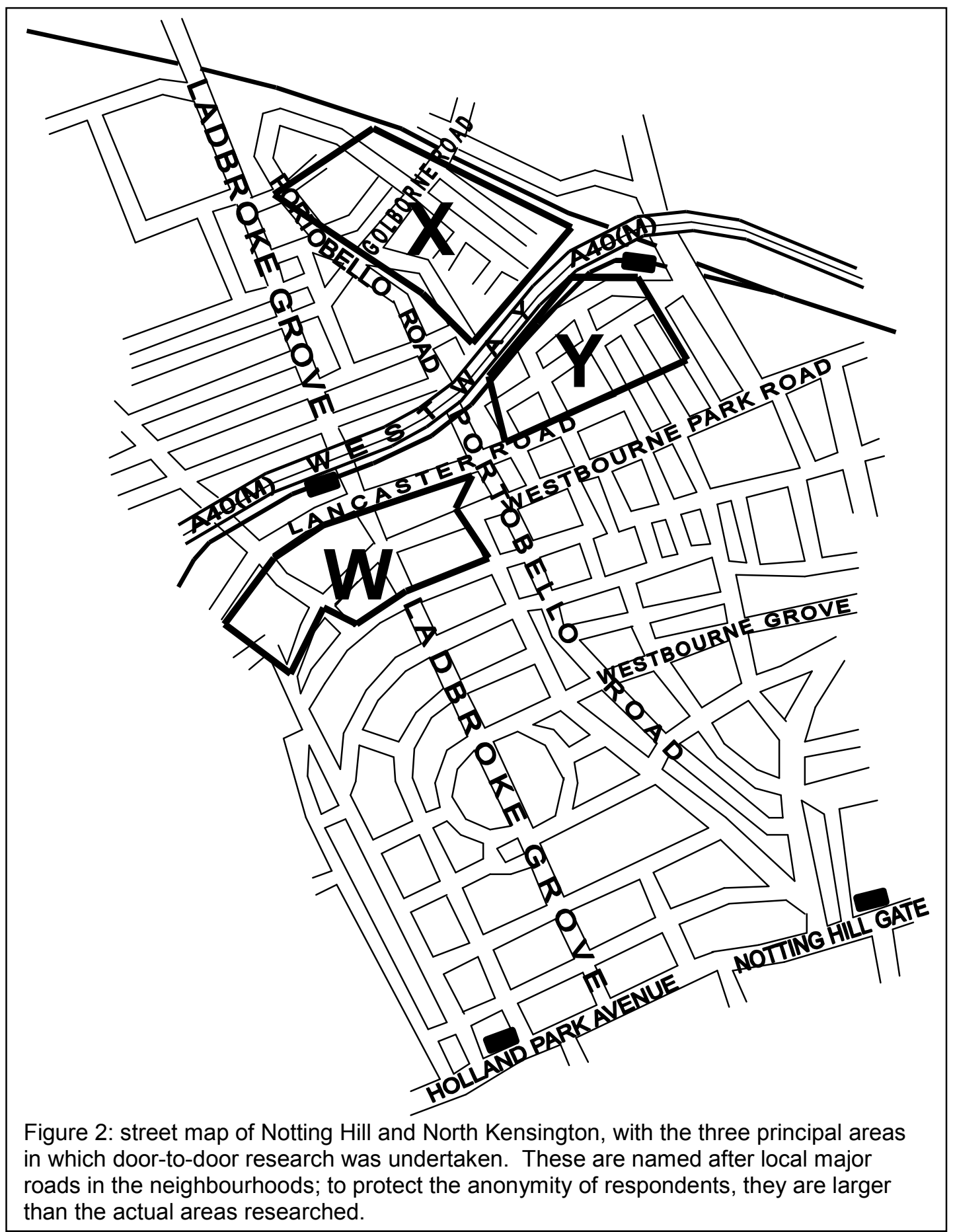

has acquired its image as "the capital's trendiest district" (Guardian 27 April 1999), epitomised in the release of the film of the same name. Despite all this, though, the area retains a good deal of poorer neighbourhoods, and gentrification remains very much an incomplete process.

An area such as Notting Hill, so subject to the disorientating processes of gentrification and mediated representation, would seem a potentially fascinating place in which to research the place-meanings held by marginal or subordinate groups through direct qualitative research. With this approach I hoped to obtain a more nuanced understanding of the ways in which people negotiated the multiple meanings attached to their place, and whether the impression given by the likes of Smith and Zukin, of valiant resistance to gentrification ultimately succumbing to the hegemonic power of gentrifiers and developers, was borne out.

In the next section I review in more detail some of the literature about gentrification and 
globalization in the postmodern city, and then provide a brief description of the area of Notting Hill and the way it has been represented. I then explain how the research was carried out before presenting and discussing the results of the study.

\section{Gentrification and globalization in the postmodern city}

Much has been written about the emergence of a 'postmodern urban landscape' in which the 'post-industrial' order of class polarization transforms the structure of urban space through associated processes, including gentrification (Harvey, 1987, 1989; Zukin, 1992). These material spatial reconfigurations bring the more abstract traits of postmodernity into sharp, localized relief. In gentrification we see reflected the process of 'deterritorialization', in which traditional spatially defined sources of identity such as the neighbourhood become increasingly fluid and uncertain (Appadurai, 1990). Globalization amplifies this process, as local cultures and spatial forms are appropriated and redeployed as aesthetic gloss in the marketing of the city in an increasingly competitive global marketplace (Harvey, 1989). Difference is reduced to controlled and carefully presented 'multicultural gloss' in the selling of places by city authorities, developers and 'boosters' (Soja, 1989; Sorkin, 1992).

The social and spatial restructuring of the city through gentrification, then, is crucial to this reimaging of places. In Neil Smith's (1996) account, economic forces are dominant in initiating gentrification, as a relative decline in land-value permits developers to profit from neighbourhood 'rehabilitation' within the wider uneven development of the city. Changing occupational structures - the creation of the so-called 'new middle class' - have brought with them new tastes and 'lifestyle choices' which interact with these 'production-side' processes to effect gentrification (cf. Ley, 1994). Zukin (1991, 1992; see also Reid and Smith, 1993) focuses more closely on how such 'cultural' processes dovetail with economic structures in gentrification, identifying the role of the heterogeneous band of investors, gentrifiers, artists and entrepreneurs who serve to reassert the 'lost' heritage of the neighbourhood concerned:

The cultural value of modern cities must be explored, explained, and affirmed by contemporary artists and intellectuals. This group establishes the proper perspective for viewing the historical urban landscape. By their labour as well as their cultural products - especially cultural critique - they act as a critical infrastructure in the postmodern urban landscape. (Zukin, 1992: 229)

In the establishment of this 'proper' perspective on the landscape, alternative readings are wiped out. Local particularity is appropriated by the market as this group "[encourages] a re-viewing of the nondescript, segmented vernacular as a coherent landscape of power" (Zukin, 1991: 204). Much the same process is at work in the marketing and representation of places in the mass media: the imposition of a perspective on place on which the local population, especially its disenfranchised sections, may have minimal influence. Smith (1992) documents how the media discourse of gentrification as the colonization of previously 'untamed' territory has been applied in the selling of the trendiest restaurants of newly gentrified areas. "Social conflict is recast as artistic spectacle, danger as ambience" (Smith, 1992: 77; cf. Eade and Mele, 1997).

Politics, too, becomes aestheticized in the postmodern city. Smith (1992: 77) writes eloquently of how street art and graffiti protesting the gentrification of the Lower East Side "came off the trains and into the art galleries"-resistance appropriated and commodified:

Urban pioneers seek to scrub the city clean of its working-class geography and history. By remaking the geography of the city they rewrite its social history as a justification for its future. Slum tenements become historic brownstones, and exterior facades are sandblasted to reveal a future past. ... If the past is not entirely demolished, it is at least reinvented - its class contours rubbed smooth-in the refurbishment of a palatable heritage, oozing fake authenticity. (Smith, 1992: 89-90)

With resistance, heritage and local identity so easily incorporated into the landscapes of power of 
the dominant, Smith and Zukin are negative about the prospects for regaining a place-based symbolic identity that resists co-optation. All political action, all community activism, becomes, in these representations, subservient to the selling of places to the gentrifiers of the new middle class, and the brute force of capital ultimately crushes the symbolic resistance of the incumbent population just as it drives it out materially. Is the cultural hegemony of postmodern capitalism such that there really is no space left for resistance?

Some, such as Eade and Mele (1997), have suggested that the cultural influence of globalization actually offers local communities positive opportunities for influencing placeimages, by altering the terms of engagement between developers and incumbent populations. Thriving, diverse communities are an asset in themselves in terms of place marketing, they argue, but this still seems to imply an aestheticization of difference in the name of selling place, albeit in a more democratic manner. Others suggest that even in heavily represented places there remains room for alternative constructions of place which are not devalued in this way (Massey, 1995; Rose, 1995). And so, as Massey (1991: 28) argues in relation to poly-ethnic Kilburn,

people's routes through the place, their favourite haunts within it, the connections they make (physically, or by phone or post, or in memory or imagination) between here and the rest of the world vary enormously. If it is now recognised that people have multiple identities then the same point can be made in relation to places.

In this context, globalization might turn out to be the inspiration for a new 'politics of place', one which goes beyond a regressive, inward-looking 'false consciousness' and instead "can build on a notion of places as social relations rather than bounded enclosures and an understanding of centre-periphery relations and migrant settlers" (Eade, 1997b: 10, citing Massey, 1993). In other words, the local results (including gentrification) of global processes might open the possibility of a progressive politics of place which acknowledges "the absent and distant as ... integral to the local" (Albrow et al., 1997: 23), a politics which, in recognizing the centrality of global structures in local processes, might avoid both regressive exclusivism (such as that encountered by Cohen, 1996) and the aestheticized, anaesthetized celebration of difference (as depicted by Smith, 1992, above). We should be cautious, though, in our expectations, for working-class communities touched by the hand of global forces - migration, gentrification, post-Fordism - may just as likely resort to traditionalism, localism and xenophobia, as found in diverse British contexts by Cohen (1996), Eade (1997a) and Back (1998), among others. We do at least, though, have a starting point from which to attempt to understand how subordinate groups might maintain an attachment to place which does not yield to the colonizers' symbolic and material power. Let us now consider the specific context of Notting Hill in relation to this.

\section{Images of Notting Hill}

Few neighbourhoods in London, and perhaps in the world, can have been subject to the parallel assaults of mediated representation and gentrification to quite the same degree as North Kensington since the 1990s. To the outside world it has been depicted most famously and infamously in the film Notting Hill, but also in countless other popular media accounts, as the 'hippest' place in the capital. The creeping material colonization of Notting Hill arising from gentrification has been matched and even exceeded by the 'imaginary colonization' of the plethora of mediated representations of the place. Such representations are arguably archetypal of the kinds of sanitized 're-imaging from above' discussed in the previous section. We shall touch on this more concretely shortly; let us first, however, briefly consider the recent history of the area to put the experiences of gentrification and the media gaze into context.

The built environment of Notting Hill as it appears today began to take shape in the middle of the nineteenth century, part of a belt of well healed houses on the western edge of central London. The district's population was among the wealthiest in London, though a survey of Charles Booth's Life and labour of the people of London (1902) shows less salubrious areas on its fringes. From the 1880s onward these areas expanded as the large houses were subdivided into 


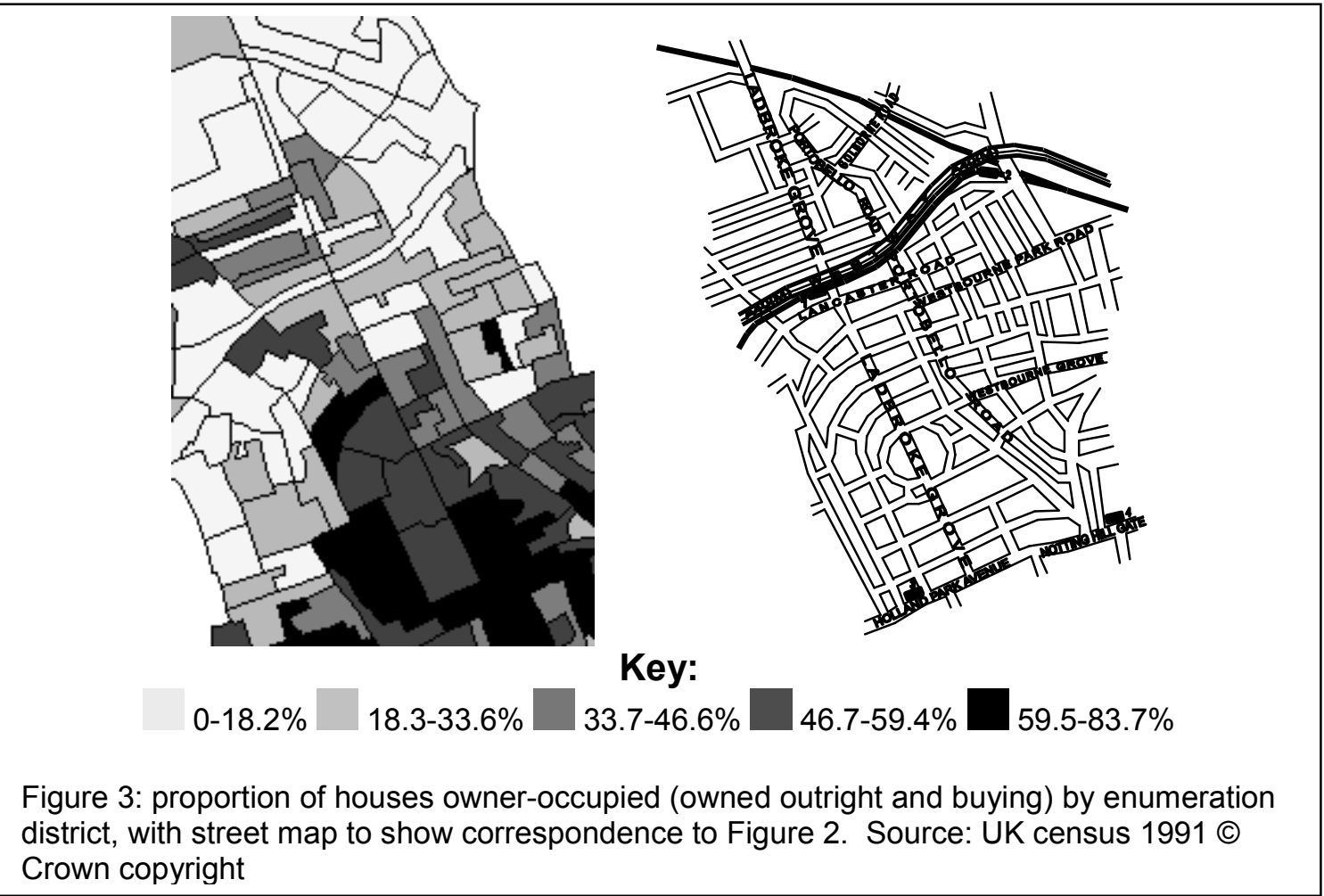

flats, initially for the immigrant Irish population. This process continued into the twentieth century, until "in the 1950s and 1960s ... these houses were subdivided yet again, four families filling the space where just one family had lived before" (O’Malley, 1977: 9). By this time the area was receiving overspill populations from nearby War-damaged areas, and the first migrants from the Caribbean. Living conditions declined rapidly as unscrupulous landlords, including the notorious Peter Rachman, took advantage of the deregulation of the rented accommodation sector to fill the Victorian houses with as many black tenants as would fit, the legality and propensity of racial discrimination making it difficult for them to find anything better (see Pilkington, 1988; Western, 1993). Glass (1960: 50) describes the prevailing conditions in much of North Kensington at this time:

The tall houses, structurally similar to those of the south, are badly in need of repair: the woodwork is unpainted; window frames are rotten; plaster has fallen away from the outside walls. ... Occasionally, there is a gap in a long parade of terraced houses: the missing house seems to have fallen down. These are the streets of transition where a considerable number of West Indians have found homes.

In 1958 Britain's first 'race riots' occurred in Notting Hill and Nottingham, involving violent attacks on the black residents of the area (Hall, 1978). From the 1960s onward, however, the Notting Hill Carnival emerged, initially as a poly-ethnic expression of class unity (Cohen, 1980), its character subsequently developing through to its current incarnation as a massive event subject to national media coverage. Gentrification was also beginning in earnest (see Western, 1993; cf. Hamnett, 2003), but even today the area remains socially heterogeneous (see Figures 3 and 4); indeed, alongside the most recent surge of gentrification there has been a new wave of ethnic minority settlement, in the form of the Moroccan community which now occupies a northern section of the area around Golborne Road. ${ }^{2}$ By way of illustration of the area's

\footnotetext{
${ }^{2}$ Very little academic literature exists on Moroccan immigration to Britain, less still on the Moroccan community of west London. According to information from the Kensington and Chelsea Community History Group (see www.golbornehistory.org.uk), Moroccans started to arrive in North Kensington in the 1960s to work in the catering trade, and the community
} 


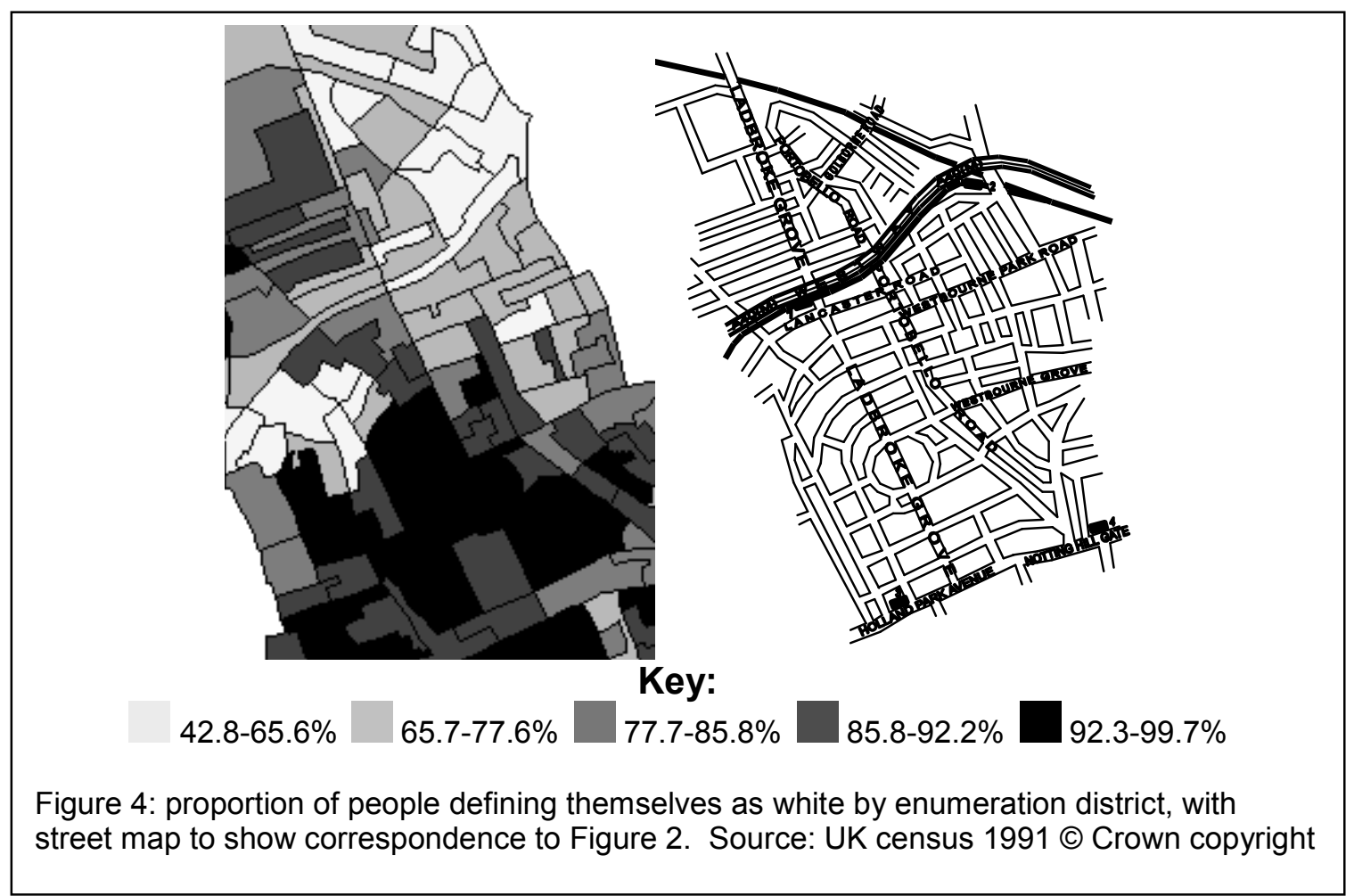

persistent social mixture, Figures 5 and 6 show the southern and central parts of Ladbroke Grove, a main road running through the heart of North Kensington, whose appearance reflects the changes in character of the area over a very short distance.

This historical and contemporary heterogeneity has undoubtedly aided the Bohemian image of Notting Hill propagated through the media: 'diversity' and 'multiculturalism' are wellknown selling points in the marketing of places to the 'new middle class', and it is indeed to these kinds of traits which Richard Curtis, writer-producer of Notting Hill the movie, appeals in his description of the area on the film's website:

Notting Hill is an extraordinary mixture of cultures. It is rich and poor and Portuguese and Jamaican and English, and it seemed like a proper and realistic place where two people from different worlds could actually meet and co-exist. ... Notting Hill is a melting pot and the perfect place to set a film. (http://www.universalpictures.com/nottinghill/behindscenes/)

This quotation might seem a quintessential example of the objectifying gaze of the flâneur or gentrifier, in which cultural and ethnic diversity are reduced to aesthetics, and social conflict, as in Smith's (1992) account, to spectacle or 'ambience'. Yet what is interesting about the film, noted by many critics at the time of its release, is quite how completely it managed to exclude diversity in its representation of the area. Cultural variety did not form the aestheticized backdrop to the film's plot: it hardly featured at all. In the words of Ferdinand Dennis (Guardian, 31 March 1999), "[Notting Hill] caters for that romantic Anglophile view of [London] as that mono-cultural, mono-racial city beloved of American Wasps." Carnival, surely an important part of the local calendar in anyone's book, did not feature at all, and economic inequalities were likewise also written out of the plot.

Notting Hill is not the only mass-media portrayal of the area (see, for example, MacInnes, 1959; Amis, 1984, 1989, 1995; Fielding, 1999, which give arguably more nuanced depictions of North Kensington), but it is certainly the most famous. And this image of the area has only been

became established from the 1980s onward. The Moroccan population of North Kensington is the largest in the country. 
This is an electronic version of an Article published in International Journal of Urban and Regional Research 29(1): 67-88. @ 2005 Joint Editors and Blackwell Publishing Limited

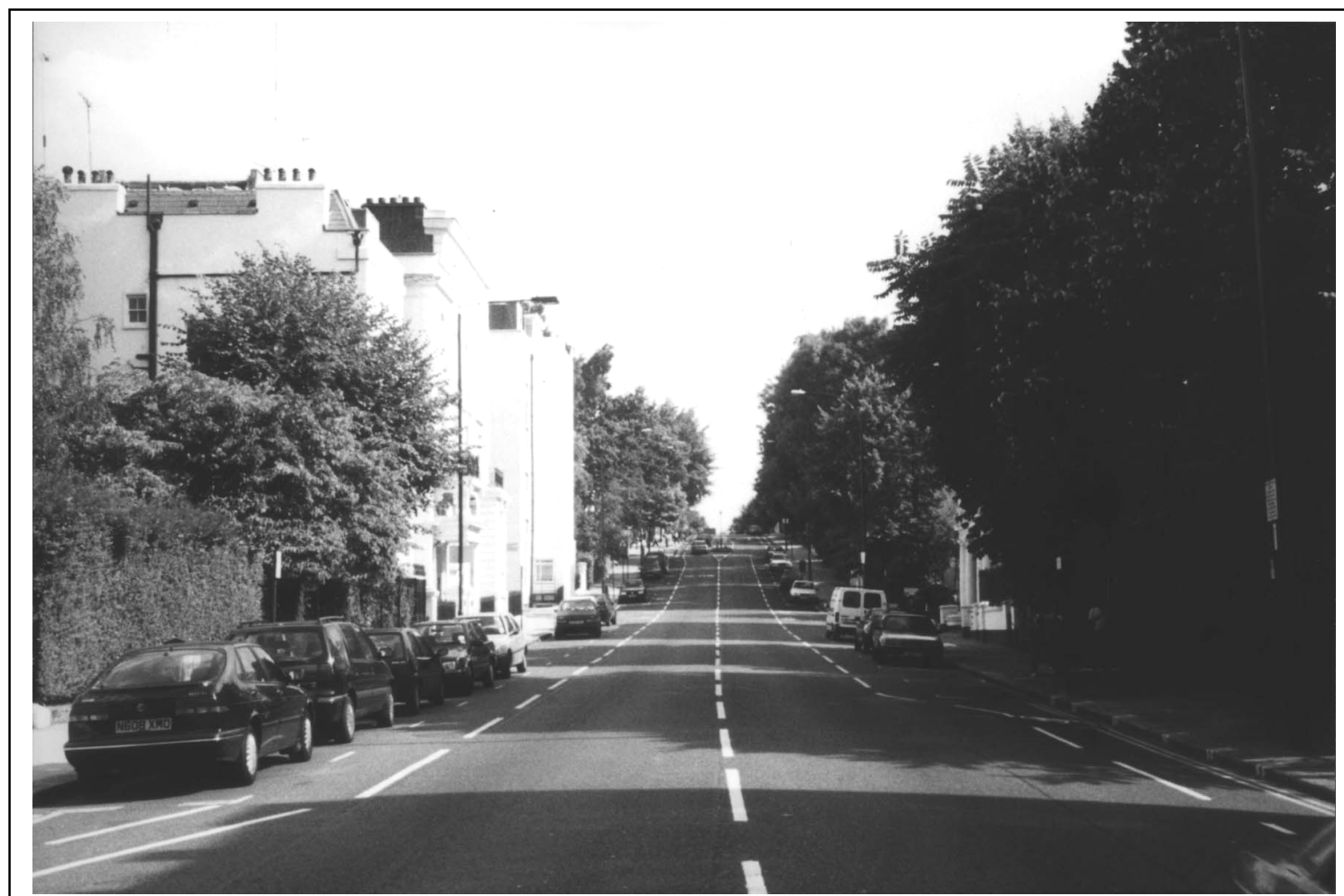

Figure 5: the southern, richer end of Ladbroke Grove

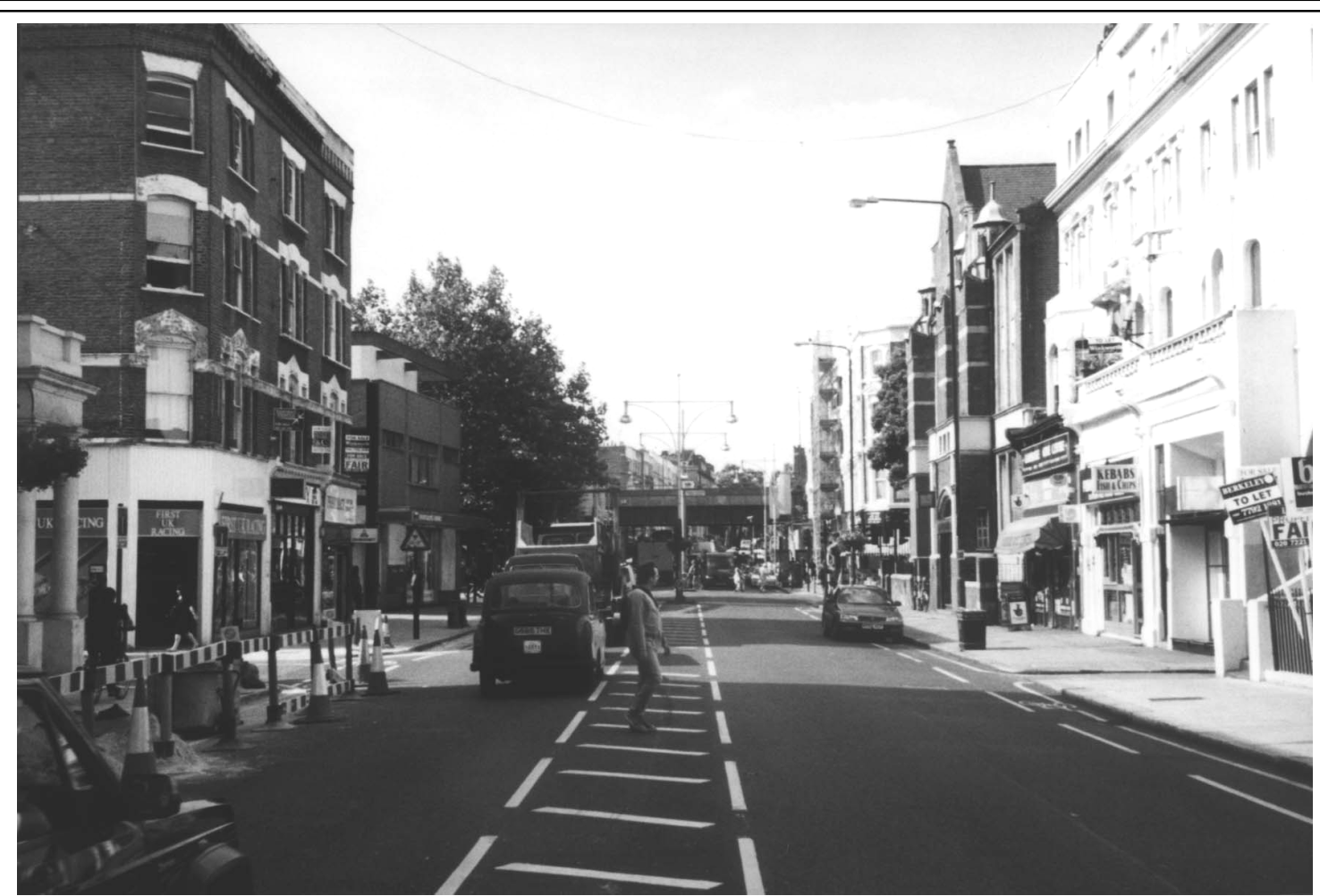

Figure 6: Ladbroke Grove towards the Westway motorway (centre of picture)

furthered since the film, as it has become the home of ever more noted celebrities and even plusher restaurants. But what of the residents of the area who do not fit this mould, for whom this material and symbolic colonization is leading to increasing marginality as the identity of Notting Hill is so transformed? How are they able to retain their own sense of place in the face of such power? These were the questions that informed this research. 


\section{Method}

The aim of the study, then, was to explore the place-image of Notting Hill constructed by those among its inhabitants whose ideas, perhaps, were not so frequently represented as the dominant portrayals treated above (Martin, 2001). Among such groups, however, there is no reason to believe that a unitary picture of North Kensington should emerge (cf. Massey, 1991) — a single subordinate place-identity to oppose to the dominant place-identity-and so the aim was to consider a variety of groups' feelings, comparing and contrasting their symbolic landscapes, and exploring the 'grids of difference' (Pratt, 1998) to which respondents related in discussing place. A semi-structured interview schedule, with plenty of scope for digression, was not the ideal approach, but it did present a compromise between focus and breadth in interviews with a reasonable number of respondents. The research process involved 'cold-calling' at the doors of houses in three neighbourhoods which were all comparatively poor in Notting Hill terms, but which were otherwise divergent (Figure 2). 'Ladbroke' is a section of council-owned accommodation around Ladbroke Grove, formed into a number of self-contained estates and adjacent to one of the plushest areas of very large, predominantly owner-occupied houses to the south, with some rapidly gentrifying areas in other directions. 'Golborne' is a large area of council housing in a considerably less impressive state of repair than Ladbroke, set in a much poorer part of the district bounded by railways, the motorway and some industrial areas close to the canal. It also incorporates the principal Moroccan area of settlement. 'Tavistock' is a rapidly improving, much more middle-class area with little in common with Golborne despite its proximity, predominantly made up of small, owner-occupied houses, and with the motorway and railway to the north and owner-occupied or subdivided Victorian terraces to the south. These areas were chosen for their diversity and their differing geographical positions within Notting Hill, and it quickly became apparent just how different they were from each other, despite such spatial proximity. In particular the motorway seemed to represent for my informants the boundary between Notting Hill proper (to the south, and including Ladbroke and Tavistock) and North Kensington (to the north, including Golborne). Broadly speaking, they saw the former as prosperous and the latter much worse off. Until now, in keeping with the literature, North Kensington' and 'Notting Hill' have been used synonymously; hereafter, in keeping with most of my respondents, they will be used more precisely.

Table 1 gives some basic information on the 28 respondents with whom interviews were obtained in the three areas, and on the refusers. Some differences will be noted between the overall characteristics of the refusers compared to the respondents (mainly related to issues of language and gender), but on the whole a diverse (but not, of course, statistically representative) sample was obtained. Information on social class was somewhat difficult to ascertain-people are always very vague when it comes to matters of occupation or income-although area of residence (Ladbroke, Golborne or Tavistock), along with tenure, was a useful proxy-or perhaps represented the most significant dimension of social class as expressed in the context of Notting Hill and North Kensington: a 'local social status', in Hunter's (1974) terms, which proved telling in explanatory terms. Area of residence is indicated by a prefix of $\mathrm{L}, \mathrm{G}$ or $\mathrm{T}$ in references to respondents in the discussion below, along with other biographical details and indications of social status, both 'local' (length of residency, involvement in local social life, tenure etc.) and 'general' (ethnicity, class etc.).

Interviews were tape-recorded and transcribed where possible (a minority of cases). Transcripts and notes were then analysed and mapped on matrices in terms of key themes to permit both a biographical and thematic understanding of the data (cf. Huberman and Miles, 1998). The following discussion focuses on a few of the most interesting of these themes.

\section{Symbolic landscapes of Notting Hill}

The majority of respondents talked readily about the area and their attitude towards it. Particular 'landscapes' within Notting Hill and North Kensington emerged as especially provocative symbols of the area, rousing varied and often strongly divergent responses from the interviewees 
This is an electronic version of an Article published in International Journal of Urban and Regional Research 29(1): 67-88. ( 2005 Joint Editors and Blackwell Publishing Limited

\begin{tabular}{|l|c|c|c|}
\hline & Respondents & Refusals & Response rate \\
\hline \hline Total & 28 & 71 & $28.3 \%$ \\
\hline Female & 14 & 49 & $22.2 \%$ \\
\hline Male & 14 & 22 & $38.9 \%$ \\
\hline \hline White (British or Irish background) & 16 & 40 & $28.6 \%$ \\
\hline Afro-Caribbean & 1 & 16 & $5.9 \%$ \\
\hline South Asian & 1 & 3 & $25.0 \%$ \\
\hline East Asian & 1 & 1 & $50.0 \%$ \\
\hline French & 1 & 0 & $100.0 \%$ \\
\hline Moroccan & 1 & 7 & $12.5 \%$ \\
\hline Portuguese & 1 & 0 & $100.0 \%$ \\
\hline Spanish & 3 & 0 & $100.0 \%$ \\
\hline $\begin{array}{l}\text { Other minority ethnic (detail removed to } \\
\text { protect anonymity) }\end{array}$ & 3 & 0 & $100.0 \%$ \\
\hline Not known & 0 & 4 & \\
\hline \hline Area W & 8 & 17 & $32.0 \%$ \\
\hline Area X & 12 & 38 & $24.0 \%$ \\
\hline Area Y & 7 & 11 & $38.9 \%$ \\
\hline Other areas of Notting Hill & 1 & 5 & $16.7 \%$ \\
\hline
\end{tabular}

Table 1: breakdown of respondents and refusals to participate by gender, ethnicity and area of residence (see Figure 2). Note that where I was refused an interview, assessments of ethnic background had to be made on the basis of phenotypical and other visual/oral cues, and hence may not be accurate.

(cf. Cohen, 1985), related to class, ethnicity, neighbourhood of residence (Ladbroke/Golborne/Tavistock) and other factors.

\section{Portobello Road and Market}

Westbourne Grove, it used to be really like down to earth, now there's all these galleries and things opening. [...] If they did that with Portobello I think I would have to disagree, 'cause there it's really like, hippified, you know, everywhere you go you can smell like coffee and all these working-class people trying to sell their fruit and vegetables, and all of a sudden if places like galleries and rug shops started opening, that would just ruin the whole place. (Julie ${ }^{3}$ (L4), student, Middle Eastern background, has lived in the area for 10 years)

A central place in the film and other mediated representations of Notting Hill, Portobello featured heavily in several responses. Julie's response is typical of one set of attitudes towards Portobello, which might be seen as exemplifying a 'new-middle-class' penchant for the workingclass character of the street, a taste common among the more middle-class residents of Tavistock too. Ava (T5), another student who had lived with her lecturer mother in the area for her whole life, commented how the street had recently "escaped" a proposed McDonald's outlet, retaining its "character" despite the loss of some one-off shops due to rising rents. For David (T7), a white man working in theatre administration, Portobello has "lots of character, and there are lots of people who've grown up here, generation after generation, and they're interesting to talk to, and it would be a shame if anything changed too dramatically."

Many of those citing Portobello Road as an important local place, though, had different reasons. For the majority of respondents of relatively working-class status, the street and market were important because of their convenience and the value they provided for shopping. "Anything you want you can get there," said Phil (G1), an unemployed white man who had lived

\footnotetext{
${ }^{3}$ All names are pseudonyms.
} 
in the area for 16 years. For Anthony (G8), a young man of minority ethnic background ${ }^{4}$ and a relative newcomer to the area, "it's quite easy to go and shop there. For food shopping." For most working-class respondents, it was not the character of the road and market but their utility that was valued. To the extent that they did allude to Portobello as a symbolically important landscape, this was usually closely related to its functional value, as a convenient place to shop or meet local acquaintances:

That's Portobello Market, that's basically you come to get loads of junk on a Friday, and on a Saturday it's a lot more to buy a whole load of junk. But it's a community thing because that's how you meet everybody 'cause a lot of people round here have stores and things and I would be devastated if that ever went, and it became just upmarket, trendy shops. (Sharon (G10), white woman unable to work due to illness, used to be an assistant in an estate agent)

In contrast, the more middle-class respondents tended to allude to the character of the road and market in itself in explaining their attachment to them. For Neil (T4), a white IT consultant who had recently moved back to the area after 15 years away from it, Portobello Road was "what this area of London is all about," epitomising its cosmopolitanism.

\section{Carnival}

All the residents of Ladbroke and Tavistock, which were on its usual route, had something to say about Carnival, and not surprisingly there was some correlation between attitude and ethnicity, though class and place of residence seemed more important. Those living close to the route bemoaned the noise and mess made by Carnival participants, some referring to the risk of violence or crime they perceived during the two days' events.

Even among those who found Carnival trying, though, there was a certain apologetic tone, and this applied especially to the more middle-class respondents. David's (T7) comments exemplified this:

Graham: Are there any particular places or people or events in the area that make you happy about the area or unhappy about it?

David: Well the obvious one is the Carnival. Well it's only once a year. It's great, atmosphere, love it, but it can sometimes be a bit much living in the middle of it for two days. It's nice to visit, but sometimes I try and get away. 'Cause obviously the rubbish, and the huge amount of people can be a bit overwhelming.

Graham: So you do enjoy it, but it's just a bit too close for ...

David: $\quad$ Oh I love it yeah, I mean I always sort of pop out for a few hours and join in, but then once you've done that you want to come home for a bit of peace and quiet, you can't.

Some middle-class informants actually felt that middle-class newcomers to the area in general were much more hostile towards the event: apparent displays of cultural capital in distinguishing themselves - the more modest middle classes, usually of Tavistock-from the vulgar, rich newcomers (cf. Butler, 1997). Peter (G7), privately educated but resident in the area for 20 years, and the only respondent from Golborne who could be unequivocally described as middle class, said that his middle-class acquaintances left the area during Carnival. Yet among my respondents, those who said they went away during Carnival were predominantly working-class white people.

\section{The area as a whole}

Most respondents were happy with the area overall, especially those who had lived there for a long time. But for many, especially those of more working-class backgrounds, this was sometimes tinged with ambivalence: Doreen (L8), a retired white woman in her 60s resident in

${ }^{4}$ Precise detail of ethnic background of some respondents is removed to protect anonymity. 
the area for 35 years, averred that "I do feel at home here because I've lived here too long. I think it's more ... being used to it, you know." Doreen and several other respondents who expressed a sense of 'feeling at home' in the area felt that this was more to do with the number of friends they had in the locality or the amount of time they had lived there. For many, especially those in Ladbroke and Golborne, there was no sense of being, as David (T7) put it, in "the place to live" in London, and although usually aware of the image of the area presented in the media, they certainly did not feel it.

There was, however, a marked difference between the generally positive responses of those living in Notting Hill 'proper' (Ladbroke and Tavistock) and those in Golborne to the north. Though a significant minority here stated they liked the area, others highlighted the neighbourhood's problems: drugs, crime and racial tension.

These children, instead of enjoying life like they should, they've grown up fifteen sixteen. And drugs are so easily available to them and easy to sell and that's all they do. [...] That seems to be the main problem. It's not sort of smoking, you know, like marijuana, that's not really a problem, it's crack and heroin, it's ugh. (Sharon (G10))

The police arrested a lad yesterday. It's noisy, 'cause they're dealing late at night. [...] During summer it's quieter because the young Moroccans go home on holiday. Some of them are very rude. (Janet (G12), woman of Dominican background in her 50 s, works as a cleaner)

The contrast between this area and the area to the south of the motorway was stark, as several residents of Golborne made clear. Gill's (G6) response to my (ill-advised!) attempt to question her on the merits or otherwise of Notting Hill (the film) exemplifies a geographical divide perceived by many in North Kensington:

Gill: Well North Kensington's nothing like Notting Hill at all. Notting Hill's rich.

Graham: Do you mean Notting Hill as in the area?

Gill: Yeah. Once you move up through that area, the houses are huge, although a lot of them are subdivided, but it's a very different area, lots of posh restaurants, film stars ... It's a whole different atmosphere when you're up there. And people down here ... For example if I was going to walk round with a camcorder round here, I'd put it in a child's lunchbox, I wouldn't walk round with it in a bag like that. Whereas in Notting Hill, people do. [Laughs]

Graham: Yeah, yeah.

Gill: I think most people feel it's a poor relation down here, we're always ... tagged on the end.

This contrasted intriguingly with the way respondents in the other two areas tended to speak about the locality. For those in Ladbroke, who tended to be similar in terms of social class, the division between neighbourhood and the wider Notting Hill was relatively seamless-though their estate was clearly quite distinct from, say, the southern end of Ladbroke Grove, respondents talked about the two in a relatively fluid manner. Tavistock's more middle-class inhabitants, meanwhile, tended to see their neighbourhood very much as part of Notting Hill, but distinctive: cheaper, somewhat poorer, less snobbish, less scarred by gentrification. Class, then, seemed to play a part in this microgeographical disparity, but did not account for it all.

The film

My question on Notting Hill and media representations of the area in general elicited some interestingly divergent opinions. However, many respondents did not have strong feelings either way about the film, and among those who did, issues surrounding its authenticity (or otherwise) seemed to be of interest to relatively few. Respondents commonly referred to the increased 
number of tourists in the area: this was generally seen as a nuisance, though some were glad of the economic benefits they perceived this as bestowing. Others, though, had rather different opinions on the material effects of the movie. For Sharon (T10), who had lived in councilowned accommodation in ungentrified North Kensington for about 20 years, the biggest issue was the film's effect on commercial lettings:

[The film] was devastating for shops and a lot of my friends have had shops in the area and they couldn't afford to pay the rents any more, people see the opportunity to put the money up and they do because ... why not, I suppose. But it has knocked a lot of the community out because of it. A lot of pubs have had to change into trendy pubs, I mean all the places that me and my partner used to go to, we couldn't even afford to go in the front door now. And that's quite sad, what's left is just some very dingy, grotty pubs.

\section{Neighbourbood change— and continuity}

Change in the area was another theme specifically addressed in the interview schedule, but the responses to my questions relating to this were surprising. Many interviewees perceived little if any transformation. And when respondents did make reference to changes, they were as likely to be about supposedly insignificant, quotidian matters as about gentrification or cultural globalization. Take Fiona (L6), a retired woman originally from the Philippines who had lived here now for 19 years:

Graham: Would you say the area is changing?

Fiona: Oh yes, tremendously, it changed a lot.

Graham: How would you say then?

Fiona: There are street lights, there are more street lights now, and let me think, most especially Saturdays now and Fridays there's a lot of tourists walking around. Fifteen years ago it's very dark in this area. [...]

Graham: Are there any ways it's changed for the worse?

Fiona: Well I couldn't think of anything ... Oh yeah, they stop children from playing around the estate, although they put no bicycle, no playing balls [signs], still they do it and they make a lot of noise. That's one thing that gets worse since I get here. Children playing around, knocking doors.

Other residents did cite gentrification as a significant development, although not all saw it as a problem: for some, it really had no impact either way, and one or two working-class respondents actually welcomed their richer neighbours. For Aicha (G2), a young woman of Moroccan background who had grown up in the area, the gentrifiers were making the local environment safer. Doreen (L8) felt that the newcomers represented "a better class of people." For many residents of Golborne, however, there were rather more pressing changes than the relatively remote prospect of gentrification. Many perceived North Kensington to be in a state of decay, with the problems of drugs, violence and a generally threatening male 'youth culture' apparently spiralling. And if there was a problem with 'intruders' new to Golborne, it was not the gentrifiers who concerned people the most.

North Kensington's newcomers

Gill: There's been money come into the area to tidy it up, which needs to happen on a very constant basis. There is a feeling that the money gets spent on certain parts of the community more than others.

Graham: Which parts do you mean?

Gill: Moroccan. Moroccan community.

Graham: And that's at the expense of other groups in the area?

Gill: $\quad$ Yes.

Though it was far from a concern for all residents of Golborne, of those who felt that the area's 
character was changing, the arrival of a Moroccan population was foremost in the minds of most. This theme meshed with a concern about the lack of facilities in North Kensington and the general overpopulation of the neighbourhood (relative to other parts of the borough) to fuel resentment on the part of some residents of Golborne. For Gill (G6), it was the fact that the Moroccan community was too 'inward-looking':

There's a large number of Moroccan people who go to their own advisers, their own youth clubs, colleges, whatever, and don't mix, whereas if it's a mixed group, it works. [...] There's a Moroccan community and there's another community. Sometimes they're together, like at the school or whatever, they're linked, but there's a huge new mosque that's been built and a lot of people come into the area and just use that, and the Moroccan facilities, the shops.

Sharon (G10) saw the problem as a matter of the population outgrowing the area, along with a lack of provision for the area's youth, Moroccan or otherwise:

Sharon: When I first came into this area, they were just little tiny kids, but it's those, it's the Moroccan community and the Portuguese, they've grown up now, so that's where it's all started from, it's like another generation. [...] I mean I'm living in a Moroccan kind of community here, and there's a few Portuguese, and Spanish. The rivalry between these families now they've all got bigger, and it's their families have expanded, you know it's just ... It's hard to explain sometimes.

Graham: So you mean there's a rivalry between different communities for ...

Sharon: It's more the communities now because they're getting larger, as the children are growing older, it's getting bigger and bigger, and it's ... Here, I mean I feel that there's a lot of a cultural thing, a lot of fighting that way. And English, you just keep quiet.

What such accounts had in common, then, was reference to distinct 'communities' whose differing cultural norms lead to friction (cf. Gilroy, 1987), whether it be due to the building of a new mosque or the "cultural thing" causing conflict.

\section{Re-enter gentrification}

But it would be unjust to portray the informants above as exhibiting an unreflexive racism or straightforward xenophobia. Rather, in this deprived neighbourhood, where "they just bung too many people into one small area" (Sharon), the arrival and growth of the new community was simply the clearest manifestation of overpopulation coupled with underprovision of resources. This becomes clearer if we consider Gill's comments in context: from speaking about the problems related to the Moroccan community, she goes on to discuss

a definite lack of housing in the area, particularly sort of larger houses. Along this road, there are lots of people who, they're all two bedroom properties, they have far too many people to live in two bedroom properties. But there's nowhere to go, you have to spend years on a waiting list. [...] Some of the council houses along here have been sold off, they get rented out at huge amounts [...] which nobody can afford to pay, so there are groups of people who shouldn't be here, people earning their money illegally, or people who don't get housed otherwise by the DHSS, who seem to be able to do whatever they want.

Her anti-Moroccan (or, more specifically, anti-Moroccan community) sentiments, then, emerge as part of a wider constellation of concerns about the material deficit in the area. She resents the decline in provision enjoyed by the incumbent population of North Kensington, in which she explicitly includes "Irish, Caribbean, Portuguese" people. Gentrification connects to this concern, as in the passage above, but its impact for her-as a council tenant, a mother of small children and a longstanding resident of Golborne-is marginal in comparison to the lack of local 
authority patronage and the intrusion of the Moroccan community.

In the self-contained enclaves of social housing that made up Ladbroke, too, gentrification was no more than a passing concern: of more worry here were more local issues, for example the management and cleanliness of the estates. By way of contrast, for many of the respondents in relatively affluent Tavistock, gentrification was a much more central issue. Their feelings about it were mixed, and none of my interviewees was completely positive about the process. The owner-occupiers among them acknowledged the benefits they enjoyed from rising house prices, but were then quick to add the difficulties these often implied for other residents:

The property values have gone up so sky high that [my sons] will never be able to live in this area if they want to come back. It's been taken over by the upper kind of people really. For instance the pub near me has become an organic pub. Which means that the beer is four pounds a pint. [...] I'm OK because the value of this [house] has gone up, that's on a personal basis. But overall it doesn't do much good for the people who have been living here and their children. (John (T1), middle-aged owner-occupier of minority ethnic background, works in advertising for an airline)

Neil (T4), meanwhile, commented that rent rises meant smaller, irreplaceable shops being shut down- "but you do get better restaurants." Middle-class concerns about the implications of gentrification for the working-class residents of the area were matched by worries about the loss of 'character' that such changes were bringing. At the same time, middle-class respondents acknowledged that this loss of symbolic landscapes, and potential material consequences of gentrification for poorer neighbours, could result in material improvement for them-in the form of rising house prices, better restaurants and so on.

\section{Discussion}

What might already be clear from the preceding presentation of some of the data is that there was something of a 'phenomenological gap' between my own 'authorial intentions' as interviewer and those of the working-class respondents in particular. Their concerns and mine did not entirely correspond. General questions about place identities most frequently elicited specific answers about the functional utility of places; inquiries about how the neighbourhood had changed, which I expected respondents to relate to gentrification and associated processes, were just as likely to be met with references to improvements or deterioration in the estate. One could put this down to a failure of primarily semi-structured and relatively brief interviews to access the 'deeper' sentiments of the respondents. Equally, though, it could be attributed to the very openness with which I sought to frame my questions. I acknowledge that my method precluded some more complex ideas coming through in the research, but that methodology was consistent between middle-class and working-class respondents and yet this difference remained. At the least, then, what we appear to have is a difference between the more immediate concerns of respondents in the different neighbourhoods, and of different class statuses: their readily thought-out and 'abrupt' sentiments.

\section{Gentrification: a middle-class concern?}

Of course, the concern about gentrification felt by the more middle-class respondents should in itself come as no surprise. The earliest writers to describe gentrification stressed the social cachet of those middle-class individuals moving into predominantly working-class areas (Glass, 1973), and the more recent gentrification literature emphasises the social differentiation within gentrifiers as a group (Ley 1994; Butler, 1997; Bridge, 2001; Robson and Butler, 2001), as influenced by Bourdieu's (1984) work on the strategies used by members of classes to affirm their status. This was certainly in evidence among many of the more middle-class respondents of Tavistock, who often saw themselves as quite distinct from the less sensitive/reflexive, richer gentrifiers elsewhere in Notting Hill. The combination of inverse and conventional 'snobbery' is perhaps best illustrated with reference to Neil (T4) (see Box 1).

Neil's reference to the influence of large corporations on the housing market accords with 
This is an electronic version of an Article published in International Journal of Urban and Regional Research 29(1): 67-88. ( 2005 Joint Editors and Blackwell Publishing Limited

Neil, a middle-aged IT consultant, moved back to the area four years ago, having previously lived here in 1984. He and his wife chose to live in this part of London deliberately, for its convenience and its character. He likes the area's cosmopolitanism, but feels that this is being lost as the place becomes more expensive: in 10 years' time, he feels, it will not be recognizable, thanks in part to the film, which is helping to turn the area into Chelsea. Along with this, large firms such as Shell are buying up properties around Notting Hill Gate en masse to house overseas guests during their stay in Britain: it is cheaper than hotels and the visitors prefer it. This part of Notting Hill, though, is not as bad as the southern end of Portobello Road- "Snotting Hill" as he calls itbut you can see the gentrification making its way north, pushing out 'real' people. As gentrification overtakes this part of the area, he plans to move elsewhere.

Box 1: Neil

Gill, resident in the area for 11 years, is a housewife, her husband working for London Transport, and rents her house from the local authority. For her, the area has a number of problems: the lack of facilities for children mean those excluded from school simply become "a menace"; drugs are abused all over the estate, including the children's play area across the road and her own front garden. Furthermore, what money there is available to the neighbourhood, she feels, gets siphoned off for the Moroccan community, who tend to opt out of communal provision, undermining the facilities provided for all. She finds herself caught between an underproviding borough, an expanding and inward-looking Moroccan community and a creeping gentrification that is leading to council-owned property being sold off and rented at exorbitant rates. For her, North Kensington and Notting Hill are completely different social worlds despite their proximity.

Box 2: Gill

Peter, a public school-educated photography director in his 20s, has lived in this house for two years and in the North Kensington/Notting Hill area for his whole life. He too rents from the council, but is looking to buy soon. He loves the area- "it's my manor"-and although he knows it has changed a lot thanks to gentrification, it has retained its multicultural roots, though it's not as friendly as it once was. For him, the neighbourhood has its problems, though no more than any other council estate, and gentrification has cleared it up a lot: for example, drugs and associated problems have been pushed up towards Harlesden. In 20 years' time, he suggests, this area will look just like the plushest parts of Notting Hill: the children's playground (which according to Gill is presently a dealing ground for the drugs pushers) will have become a key-locked residents' garden. He recognizes the benefits gentrification brings him and realizes he is part of it, but he does resent the way in which working-class people are 'written out' of the accounts of the area penned by the media-types he knows.

Box 3: Peter

Butler's (1997) distinction between individual-led and 'structural' gentrification. Concerns about the effects of gentrification were a feature of the (new-) middle-class consciousness of the relatively rich respondents-but these were apparently genuine concerns for the wellbeing of those being pushed out rather than a simple display of cultural capital or an 'aestheticization of difference' as identified by May (1996) in relation to gentrifiers in Stoke Newington (even if some respondents were blissfully unaware of their own impact).

In contrast, working-class informants seldom mentioned such change-with the key exception of those for whom it was an important and proximate material issue. In Ladbroke, respondents referred to change on their estates, relatively bounded and protected areas of council housing in parts of Notting Hill which had been well heeled long before recent gentrification. In Golborne, there were more pressing matters than gentrification. Contrast the (already familiar) testimonies of two neighbours in Golborne, relatively working-class Gill (Box 2) and resolutely middle-class Peter (Box 3).

Now there is more than just the 'general' social status of 'class' at work here (cf. Hunter, 1974)—-most obviously, Gill's family might make her more aware of the drugs problems in the 
playground than childless Peter, while his self-declared intention to buy a house soon might detach Peter from the immediate problems of the neighbourhood and give rise to his preoccupation with gentrification and vision of how the area will be transformed 20 years down the line. Nevertheless, Peter shared his fixation on gentrification, and particularly the symbolism of gentrification, with most middle-class respondents, while the concern for the more pressing material issues displayed by Gill was a common feature among many working-class respondents, particularly in Golborne. Gentrification was only a concern for them inasmuch as it affected their day-to-day lives. This too might be considered in terms of Bourdieu's (1984) schema, specifically his comments on the 'taste for necessity' of working-class people:

Like the aesthetic disposition which is one dimension of it, the distant, detached or casual disposition towards the world or other people ... can only be constituted in conditions of existence that are relatively freed from urgency. The submission to necessity which inclines working-class people to a pragmatic, functionalist 'aesthetic', refusing the gratuity and futility of formal exercises and of every form of art for art's sake, is also the principle of all the choices of daily existence and of an art of living which rejects specifically aesthetic intentions as aberrations. (Bourdieu, 1984: 376)

This is not to imply that the symbolic dimensions of gentrification and other changes in the composition and character of the neighbourhood were disregarded in the habitus of working-class respondents. In their testimony, those who spoke of the material harm done to the neighbourhood by decaying facilities, displaced local businesses and inter-ethnic tensions frequently also articulated alternative visions, deploying symbolic ideals of a desired cohesive working-class community. However, for these relatively working-class respondents, symbolic and aesthetic judgements of the area were usually closely allied to its functional value, and to pressing material issues. In an interesting twist on Cohen's (1985) treatise on the malleability of the symbols of community, we see a contrast between symbolic landscapes 'for their own sake' and symbolic landscapes valued in material, functional terms, which distinguish working-class evaluations of the area from those of the middle-class respondents.

\section{Class and ethnicity in context}

The mesh of material concerns which informed narratives of race, class and disenfranchisement in Golborne contrasts intriguingly with the testimony of working- and middle-class respondents in the other two areas, and with other studies of neighbourhood identities elsewhere. The differences in local context have a significant effect on the structure and content of the narratives of place and community told here, such that those race- and class-inscribed tales of besiegement and change found in Golborne were hardly heard half a mile away in similarly working-class Ladbroke. There are obvious parallels with Les Back's (1996) comparison of two south London council estates, whose differing histories of housing allocation and consequently contrasting ethnic make-up resulted in very different discourses of belonging among their respective populations. Where in 'Southgate' a longstanding black and white population had lived in relative harmony, in 'Rivermead' a traditionally white community had been joined more recently by a black population at a time of economic decline, and then by refugees of Vietnamese origin who were perceived, as with North Kensington's Moroccans, to be treated preferentially by the local state. Alexander (1996) too draws attention to the importance of local context in defining the boundaries of inclusion and exclusion in a community, while Cohen (1996) demonstrates how, in east London, white working-class concerns over the redevelopment plans of the London Docklands Development Corporation gelled with xenophobia towards the area's Bangladeshi population to produce

a culture of complaint articulated by a racialized vision of the area's special history and geography. The prevailing sense of impotence and isolation was easily connected to the experience which this group had of being excluded from due political process. (Cohen, 1996: 194) 
There is also an interesting contrast with Baumann's (1996) search for a common culture spanning Southall's poly-ethnic youth. Where the boundaries of community were quickly reified by my respondents in Golborne (and by many of those of Cohen and Back), Baumann found in Southall a much more malleable notion of community which cut across ethnic groups. The key difference, perhaps, along with the longstanding multicultural character of the area, ${ }^{5}$ is the relative socio-economic homogeneity of Baumann's respondents: "Southallians appeared most readily to agree on deprecating their town: it was a place to move out of, and moving out locally was considered moving up socially. This seemed to make sense in the light of economic commonalities that reached across ethnic boundaries" (Baumann, 1996: 188). Where in Golborne, Back's Rivermead and Cohen's Isle of Dogs, race and ethnicity coincided with material issues of (sub-)class, patronage and/or neighbourhood change, in Ladbroke, Back's Southgate and Baumann's Southall such associations were not viable.

In Notting Hill and North Kensington this contrast in discourse between spatially proximate areas was striking, though it should not be greatly surprising given the nature of the social differences between the areas. Albrow (1997: 50) illustrates in Tooting how groups with "a co-present diversity of lifestyles and social configurations" may co-exist in a locality "but not thereby [create] a local culture or community" (cf. Butler, 2003). There was little commonality between the 'sociospheres', as Albrow has it, of Ladbroke, Golborne and Tavistock; rather what emerged were distinctive, identifiable narratives of place related in part to class and neighbourhood of residence. Overlap between these sociospheres occurred when, for example, the non-Moroccan, working-class residents of Golborne found themselves in direct perceived competition for resources with the Moroccan population or the gentrifiers. ${ }^{6}$

What, then, of the progressive politics of place which we anticipated might emerge amidst the local effects of global forces found in Notting Hill and North Kensington? As we have seen, middle-class responses embodied at best an often naïve, helpless concern for the plight of those displaced or marginalized by gentrification, and at worst nothing more than an aesthetically-oriented display of cultural capital; among many respondents in Golborne, the material reality of resource competition and the ideological reality of perceived cultural difference elide Massey's (1993) vision of a progressive sense of place. It seems that, as in Cohen's (1996) and Eade's (1997a) studies, these forces have had a largely divisive rather than an enlightening effect vis-à-vis the perceived root cause of neighbourhood decline. Back (1998: 68) finds a similar cognitive mechanism in relation to Asian shopkeepers among the white working-class population of a suburban Birmingham housing estate, which similarly prevents the formation of a progressive sense of place:

The local shopkeeper went from being a [white] reference point around which communal ties were cemented, to being [an Asian] symptom of white working-class marginalisation and social dislocation. The complicated economic and political forces which produced this situation could then be reduced to racial scapegoating [by the white population]. The solution, according to this logic, was merely to get rid of the Asian shopkeepers.

Gentrification and working-class loss

The implication of many writings on gentrification is that the loss of working-class landscapes is a matter of great importance to working-class people. The mournful tenor of such accounts as Zukin's (1991) on the loss of vernacular landscapes suggests a working-class regret which I only occasionally found. Some respondents even welcomed gentrification and the influx of the great

\footnotetext{
${ }^{5}$ As an anonymous referee points out, the obvious methodological differences between Baumann's sustained ethnography and my comparatively rather superficial approach here may also be a factor.

${ }^{6} \mathrm{I}$ recognize the limitations of this analysis in the absence, in particular, of a significant Moroccan group among my respondents. With Albrow (1997) I suggest this notion tentatively and speculatively.
} 
and good to Notting Hill that has occurred most recently. There is common ground here with relatively few previous studies of place and identity. May (1996) finds that some of his white working-class respondents in Stoke Newington are not wholly opposed to gentrification, as it at least keeps the area 'white'. Bridge (1994) questions the notion that gentrification destroys the social networks and community-based identities of incumbent working-class groups on the grounds that such networks are not locally confined but spread across London. From a more historical perspective, Blokland (2001) suggests that even the apparently class-based narratives of place and identity told by her working-class respondents conceal other, racialized or gendered, referents of inclusion and exclusion.

Working-class informants in this study did possess attachment to the area, but their symbolic landscapes were most often closely associated with more material, sometimes even mundane, concerns: convenience for shopping, for example, or the quality of local facilities. References to ideals of neighbourhood cohesion and working-class identity were articulated in terms of material change for the worse, not in the more 'purely' symbolic categories I had anticipated. My findings, though they arise from a limited study, would lead me to dispute the emphasis on the significance of the symbolism of neighbourhood change for working-class people in much of the literature. Much of this received wisdom is based on a discourse of place and identity which is based more, perhaps, on the insights of individual authors than on applied research, as we saw in the first section of this article.

\section{Conclusion}

From this limited study, it would appear that attachment to the symbolic meanings of place is a preoccupation mainly for those in relatively middle-class positions. This was expressed most clearly in relation to opinions about gentrification, where a middle-class regret of traditional landscapes lost contrasted with a comparative lack of concern from working-class respondents, but it was also apparent from the kinds of issues and changes which did concern respondents of working-class backgrounds. Distinctly material, and often very localized, worries were closest to their hearts, so that for the residents of Golborne in particular, the relatively distant matters of media misrepresentation and gentrification were insignificant compared to issues like crime, drugs, overcrowding, local authority neglect and most importantly of all, the perceived threat of a growing Moroccan community. Somewhat paradoxically, therefore, we find a difference in attitudes related to class where the most prominent class-based issue-gentrification-is of only marginal concern to the working-class group threatened by it. Where gentrification is of concern, however, it is in terms of its direct material impact: herein the paradox is resolved, for it is the material concerns which matter most to this group, given its position in terms of both the 'general social statuses' of class and ethnicity, and in the expression of these dimensions in the local context, through the 'local social statuses' of neighbourhood of residence, tenure and so on. Likewise, the fear of the Moroccan newcomers is not simply a case of unreflexive xenophobia, but forms part of a constellation of material issues that the respondents in Golborne perceive as impeding their day-to-day existence. Gentrification forms part of this constellation, but in the relatively protected environment of social housing it is relatively insignificant. This accords with Bourdieu's (1984) notion of the 'taste for necessity' which precludes any fixation on the more symbolic or aesthetic questions to which many of my more middle-class respondents appealed, but it conflicts with an academic discourse of the relationship between the identities of workingclass communities and attachment to place. The 'purely' symbolic dimension to place would appear then to be a relatively élite or 'merely academic' preoccupation; the emotional aspect of people's attachment to place needs to be related more closely to the material realities of their lives there. Though this is no more than the suggestion of one study with a particular and imperfect method, what is clear is that Burgess' (1990) appeal for more research into the consumption and production of place-meanings by marginal interest groups, as opposed to the interpretation of places by dominant academics, remains pertinent if we wish to understand better gentrification's many dimensions. 
This is an electronic version of an Article published in International Journal of Urban and Regional Research 29(1): 67-88. ( 2005 Joint Editors and Blackwell Publishing Limited

\section{Acknowledgements}

This paper arises from a dissertation completed as part of a MSc in Society and Space at Bristol University, for which I was funded by an Economic and Social Research Council studentship. I would like to thank Gary Bridge, who supervised the research and helped to formulate this paper. I am grateful to Tony Lemon and Hilda Parker for reading earlier drafts and providing useful comments, and to Ruth Hancock, then director of the Nuffield Community Care Studies Unit, University of Leicester, for granting me time to write this paper when I worked there. I would also like to thank two anonymous referees for their intelligent criticism, and particularly for drawing my attention to a wider literature and helping me to strengthen my analysis and presentation.

\section{$\underline{\text { References }}$}

Abu-Lughod, J. (1994) Diversity, democracy, and self-determination in an urban neighborhood: the East Village of Manhattan. Social Research 61.1, 181-203

Albrow, M. (1997) Travelling beyond local cultures: socioscapes in a global city. In J. Eade (ed.) Living the global city: globalization as a local process. Routledge, London

Albrow, M., J. Eade, J. Dürrschmidt and N. Washbourne (1997) The impact of globalization on sociological concepts: community, culture and milieu. In J. Eade (ed.) Living the global city: globalization as a local process. Routledge, London

Alexander, C.E. (1996) The art of being black: the creation of black British youth identities. Oxford University Press, Oxford

Amis, M. (1984) Money: a suicide note. Jonathon Cape, London

Amis, M. (1989) London Fields. Jonathon Cape, London

Amis, M. (1995) The information. Flamingo, London

Appadurai, A. (1990) Disjuncture and difference in the global cultural economy. Theory, Culture and Society 7.2, 295-310

Back, L. (1996) New ethnicities and urban culture: racisms and multiculture in young lives. UCL Press, London

Back, L. (1998) Inside out: racism, class and masculinity in the 'inner city' and the English suburbs. New Formations 33, 59-76

Baumann, G. (1996) Contesting culture: discourses of identity in multi-ethnic London. Cambridge University Press, Cambridge

Blokland, T. (2001) Bricks, mortar, memories: neighbourhood and networks in collective acts of remembering. International Journal of Urban and Regional Research 25.2, 268-83

Booth, C. (1902) Life and labour of the people of London. Macmillan, London

Bourdieu, P. (1984) [1979] Distinction: a social critique of the judgement of taste, trans. R. Nice. Routledge \& Kegan Paul, London

Bridge, G. (1994) Gentrification, class, and residence: a reappraisal. Environment and Planning D: Society and Space 12.1, 31-51

Bridge, G. (2001) Bourdieu, rational action and the time-space strategy of gentrification. Transactions of the Institute of British Geographers 26.2, 205-16

Burgess, J. (1990) The production and consumption of environmental meanings in the mass media: a research agenda for the 1990s. Transactions of the Institute of British Geographers 15.2, $139-61$

Burgess, J. and P. Wood (1988) Decoding Docklands: place advertising and decision-making strategies of the small firm. In J. Eyles and D.M. Smith (eds) Qualitative methods in human geography. Polity Press, Cambridge

Butler, T. (1997) Gentrification and the middle classes. Ashgate, Aldershot

Butler, T. (2003) Living in the bubble: gentrification and its 'others' in north London. Urban Studies 40.12, 2469-86

Cohen, Abner (1980) Drama and politics in the development of a London carnival. Man 15.1, 6587 
This is an electronic version of an Article published in International Journal of Urban and Regional Research 29(1): 67-88. ( 2005 Joint Editors and Blackwell Publishing Limited

Cohen, Anthony P. (1985) The symbolic construction of community. Tavistock, London

Cohen, P. (1996) All white on the night? Narratives of nativism on the Isle of Dogs. In T. Butler and M. Rustin (eds) Rising in the east: the regeneration of east London. Lawrence \& Wishart, London

Eade, J. (1997a) Reconstructing places: changing images of locality in Docklands and Spitalfields. In J. Eade (ed.) Living the global city: globalization as a local process. Routledge, London

Eade, J. (1997b) Introduction. In J. Eade (ed.) Living the global city: globalization as a local process.

Routledge, London

Eade, J. and C. Mele (1997) Global processes and customised landscapes: the 'Eastern Promise' of New York and London. Rising East 1.3, 52-73

Fielding, H. (1999) Bridget Jones: the edge of reason. Picador, London

Gilroy, P. (1987) 'There ain't no black in the Union Jack': the cultural politics of race and nation. Hutchinson, London

Glass, R. (1960) Newcomers: the West Indians in London. Allen and Unwin, London

Glass, R. (1964) Introduction: aspects of change. In Centre for Urban Studies (ed.) London: aspects of change. MacGibbon \& Kee, London

Glass, R. (1973) The mood of London. In D. Donnison and D. Eversley (eds) London: urban patterns, problems, and policies. Heinemann, London

Hall, S. (1978) Racism and reaction. In J. Rex, S. Hall, B. Parekh, A. Little and T. Huddleston, Five views of multi-racial Britain. Commission for Racial Equality, London

Hamnett, C. (2003) Gentrification and the middle-class remaking of inner London, 1961-2001. Urban Studies 40.12, 2401-26

Harvey, D. (1987) Flexible accumulation through urbanization: reflections on 'post-modernism' in the American city. Antipode 19.3, 260-86

Harvey, D. (1989) The condition of postmodernity: an enquiry into the origins of cultural change. Blackwell, Oxford

Huberman, A.M. and M.B. Miles (1998) Data management and analysis methods. In N.K. Denzin and Y.S. Lincoln (eds) Collecting and interpreting qualitative materials. Sage, London

Hunter, A. (1974) Symbolic communities: the persistence and change of Chicago's local communities. University of Chicago Press, London

Keith, M. and S. Pile (1993) Introduction part one: the politics of place. In M. Keith and S. Pile (eds) Place and the politics of identity. Routledge, London

Ley, D. (1994) Gentrification and the politics of the new middle class. Environment and Planning D: Society and Space 12.1, 53-74

MacInnes, C. (1959) Absolute beginners. MacGibbon \& Kee, London

Martin, G.P. (2001) Representation, identity and the meaning of place: the contestation of Notting Hill's landscape. Unpublished MSc dissertation, School of Geographical Sciences / School for Policy Studies, University of Bristol

Massey, D. (1991) A global sense of place. Marxism Today June 1991, 24-9

Massey, D. (1993) Power-geometry and a progressive sense of place. In J. Bird, B. Curtis, T.

Putnam, G. Robertson and L. Tickner (eds) Mapping the futures: local cultures, global change.

Routledge, London

Massey, D. (1995) Places and their pasts. History Workshop Journal 39, 182-92

May, J. (1996) Globalization and the politics of place: place and identity in an inner London neighbourhood. Transactions of the Institute of British Geographers 21.2, 194-215

Mills, C. (1993) Myths and meanings of gentrification. In J. Duncan and D. Ley (eds) Place/culture/ representation. Routledge, London

O'Malley, J. (1977) The politics of community action: a decade of struggle in Notting Hill. Bertrand Russell Peace Foundation, Nottingham

Pilkington, E. (1988) Beyond the mother country: West Indians and the Notting Hill white riots. Tauris \& Co., London 
This is an electronic version of an Article published in International Journal of Urban and Regional Research 29(1): 67-88. (C) 2005 Joint Editors and Blackwell Publishing Limited

Pratt, G. (1998) Grids of difference: place and identity formation. In R. Fincher and J.M. Jacobs (eds.) Cities of difference. Guildford Press, New York

Reid, L. and N. Smith (1993) John Wayne meets Donald Trump: the Lower East Side as Wild Wild West. In G. Kearns and C. Philo (eds) Selling places: the city as cultural capital, past and present. Pergamon Press, Oxford

Robson, G. and T. Butler (2001) Coming to terms with London: middle-class communities in a global city. International Journal of Urban and Regional Research 25.1, 70-86

Rose, G. (1994) The cultural politics of place: local and oppositional representation discourse in two films. Transactions of the Institute of British Geographers 19.1, 46-60

Rose, G. (1995) Place and identity: a sense of place. In D. Massey and P. Jess (eds) A place in the world? Places, cultures and globalization. Oxford University Press, Oxford

Slater, T., W. Curran and L. Lees (2004) Gentrification research: new directions and critical scholarship. Environment and Planning A 36.7, 1141-50

Smith, N. (1992) New city, new frontier: the Lower East Side as Wild, Wild West. In M. Sorkin (ed.) Variations on a theme park: the new American city and the end of public space. Noonday Press, New York

Smith, N. (1996) The new urban frontier: gentrification and the revanchist city. Routledge, London

Soja, E.W. (1989) Postmodern geographies: the reassertion of space in critical social theory. Verso, London

Sorkin, M. (ed.) (1992) Variations on a theme park: the new American city and the end of public space. Noonday Press, New York

Western, J. (1993) Ambivalent attachments to place in London: twelve Barbadian families. Environment and Planning D: Society and Space 11.2, 147-70

Zukin, S. (1991) Landscapes of power: from Detroit to Disney World. University of California Press, Oxford

Zukin, S. (1992) Postmodern urban landscapes: mapping culture and power. In S. Lash and J. Friedman (eds) Modernity and identity. Blackwell, Oxford 